\title{
Analysis of CTNS gene transcripts in nephropathic cystinosis
}

\author{
Anna Taranta • Martijn J. Wilmer • Lambert P. van den Heuvel • Paola Bencivenga • \\ Francesco Bellomo • Elena N. Levtchenko • Francesco Emma
}

Received: 20 January 2010 /Revised: 23 February 2010 / Accepted: 1 March 2010 / Published online: 30 March 2010

(C) The Author(s) 2010. This article is published with open access at Springerlink.com

\begin{abstract}
Nephropathic cystinosis (NC) is an autosomal recessive disorder caused by mutations of the CTNS gene that encodes for a cystine transmembrane transporter. Several mutations have been described in the coding and promoter regions of the CTNS gene in affected individuals. We selected three patients with $\mathrm{NC}$ from two unrelated families, in whom sequence analysis of the CTNS gene detected only one or no mutations. Total RNA was isolated from peripheral blood mononuclear cells or fibroblasts and CTNS transcripts were analyzed. We observed a skipping of exon 5 (85 bp) in two siblings and an intron 9 retention of 75 bp associated with partial replication of exon 9 in the third patient. Genomic DNA analysis of intron regions surrounding exon 5 showed a point mutation in the hypothetical lariat branch site of intron 4 at position $-24(\mathrm{c} .141-24 \mathrm{~T}>\mathrm{C})$ in the first two patients and a duplication of $266 \mathrm{bp}$ including a part of exon and intron 9 in the third patient. Analysis of CTNS gene transcripts allowed identification of mutations in
\end{abstract}

A. Taranta $(\varangle) \cdot$ F. Bellomo $\cdot$ F. Emma

Department of Nephrology and Urology, Division of Nephrology,

Bambino Gesù Children's Hospital and Research Institute,

Piazza S. Onofrio, 4, 00165 Rome, Italy

e-mail: taranta@opbg.net

M. J. Wilmer • L. P. van den Heuvel

Laboratory of Pediatrics and Neurology,

Radboud University Nijmegen Medical Centre,

Nijmegen, The Netherlands

P. Bencivenga

Laboratory of Scientific Research, Bambino Gesù Children's

Hospital and Research Institute,

Rome, Italy

L. P. van den Heuvel • E. N. Levtchenko

Department of Pediatrics/Pediatric Nephrology,

University Hospital Gasthuisberg,

Leuven, Belgium patients in whom CTNS mutations could not be detected by traditional DNA sequencing. These results support the hypothesis that cystinosis is a monogenic disorder.

Keywords Nephropathic cystinosis $\cdot$ CTNS gene $\cdot$ Splicing defect . DNA duplication

\section{Introduction}

Nephropathic cystinosis (NC) (OMIN 219800) is a rare autosomal recessive disorder (incidence in 1:100,000 200,000 live births), which presents with renal proximal tubular dysfunction (Fanconi syndrome) during infancy and progresses to end-stage renal failure during the first decade of life if not treated with cysteamine [1]. Over time, patients with $\mathrm{NC}$ also present with dysfunction of several organs, including eyes, thyroid, liver, pancreas, male gonad, muscles, and brain [2]. NC is caused by mutations in the CTNS gene [3]. It encodes for cystinosin, an amino-acidcystine carrier that is predicted to have seven transmembrane domains and is primarily expressed in the lysosomal membrane [4]. Lack of cystinosin activity causes cystine accumulation and results in formation of intralysosomal cystine crystals. Approximately $10-20 \%$ of CTNS transcripts encode for a second cystinosin isoform, termed cystinosin-LKG, which results from an alternative splicing of exon 12 and is expressed in the plasma membrane and other cytosolic vesicles, in addition to lysosomes [5].

The CTNS gene maps to chromosome $17 \mathrm{p} 13$ and is composed of 12 exons, with the start codon located on exon 3 [3]. The most common CTNS mutation in northern Europe is a $57-\mathrm{kb}$ deletion that originated in Germany around $\mathrm{AD} 500$ [1]. To date, more than 90 mutations have been described in the coding region or flanking intronic 
regions of the gene, as well as in the CTNS promoter, in patients with cystinosis. Of these, approximately 70 mutations cause NC. These include small deletions or insertions, missense or nonsense mutations, and splicing mutations [3, 6-13].

In clinical practice, the diagnosis of $\mathrm{NC}$ is sustained by the demonstration of increased intraleucocyte cystine levels. Genetic tests have primarily a confirmatory value and allow for genetic counseling. Evidence suggests that $\mathrm{NC}$ is a monogenic disease, although the mutation detection rate is not $100 \%$. Shotelersuk et al., for example, sequenced the CTNS gene in 108 American patients with NC and failed to detect mutations in $19 \%$ of affected individuals [6]. The CTNS promoter was, however, not analyzed in their study. Similar studies that also included the promoter region showed only heterozygous or no mutations in $18 \%$ of 46 Italian patients and in $6 \%$ of 108 French patients $[9,11]$.

In this work, we studies CTNS gene transcripts in three patients with $\mathrm{NC}$ from two families to search for mutations that were not detected at the genomic level.

\section{Patients and methods}

\section{Patients}

Among 49 Dutch patients with NC from 44 different families, we selected three patients in whom sequence analysis failed to show homozygous or double heterozygous mutations in the CTNS gene (coding regions, intron/ exon boundaries, or promoter region). Clinical data of these patients are summarized in Table 1. The diagnosis of NC was established in all patients by demonstration of increased intraleucocyte cystine levels and corneal cystine crystal depositions. Informed consent was obtained to perform the additional genetic studies included in this work.

Peripheral blood mononuclear cell isolation and fibroblasts cell lines

Anticoagulated whole blood samples were diluted with phosphate-buffered saline (PBS) (1:1), layered over Ficoll Histopaque 1077 (Sigma-Aldrich, St. Louis, MO, USA), and centrifuged at $1,800 \mathrm{~g}$ for $20 \mathrm{~min}$ at room temperature. The peripheral blood mononuclear cell (PBMC) layer was removed and washed twice with PBS following two centrifugation steps at $250 \mathrm{~g}$ for $10 \mathrm{~min}$. RNA studies were performed in patient 3 on a previously established fibroblast cell line from that patient [14].

Reverse transcriptase-polymerase chain reaction (RT-PCR) analysis

Total RNA was extracted from PBMCs or fibroblasts using TRIzol $^{\circledR}$ reagent (Invitrogen Life Technologies, Carlsbad, CA, USA). RNA was reverse-transcribed into complementary DNA (cDNA) using a first-strand cDNA synthesis kit (Roche Diagnostics, Mannheim, Germany). CTNS transcripts were amplified by PCR adding Taq DNA polymerase, PCR buffer with magnesium chloride $\left(\mathrm{MgCl}_{2}\right)$, deoxyribonucleotide triphosphate (dNTP) (Invitrogen Life Technologies), and primers (Sigma-Aldrich, St. Louis, MO, USA) in accordance with the manufacturers' instructions. Primers and PCR conditions for CTNS amplification are described in Table 2. PCR products were analyzed using a $1.5 \%$ agarose gel with GelRed $^{\mathrm{TM}}$ staining (Biotium Inc., Hayward, CA, USA).

PCR fragments were extracted and purified with gel extraction kit (QIAGEN, Milan, Italy). Transcript sequencing was performed using primers detailed in Table 2 and dye terminator cycles sequencing (DTCS) Quick Start Mix (Beckman Coulter, Brea, CA, USA) at following conditions: $96^{\circ} \mathrm{C}$ for $30 \mathrm{~s}, 53^{\circ} \mathrm{C}$ for $30 \mathrm{~s}$, and $60^{\circ} \mathrm{C}$ for $240 \mathrm{~s}$ for 37 cycles. After purification, samples were sequenced on a CEQ2000XL DNA Analysis System (Beckman Coulter).

\section{Genomic DNA analysis}

Genomic DNA was extracted from anticoagulated whole peripheral blood by QIAamp DNA blood kit (QIAGEN) in accordance with the manufacturer's instructions. The CTNS gene was amplified using primers and PCR conditions detailed in Table 2. Direct sequencing was performed with the primers described in Table 2 and DTCS Quick Start Mix (Beckman Coulter) at conditions detailed above. Samples were sequenced on a CEQ2000XL DNA Analysis System (Beckman Coulter).

Table 1 Patient characteristics

$M$ male, $F$ female, ESRF end-stage renal failure

\begin{tabular}{llll}
\hline & Patient 1 & Patient 2 & Patient 3 \\
\hline Gender & $\mathrm{F}$ & $\mathrm{M}$ & $\mathrm{F}$ \\
Age of diagnosis (months) & 41 & 48 & 18 \\
Age at ESRF (years) & 12 & 10.3 & 14.2 \\
$\begin{array}{l}\text { Intraleucocyte cystine } \\
\text { (nmol 1/2 cystine/mg protein) }\end{array}$ & 5.2 & 7.8 & 9 \\
Ocular symptoms & $\begin{array}{c}\text { Corneal cystine } \\
\text { crystals }\end{array}$ & $\begin{array}{c}\text { Corneal cystine } \\
\text { crystals }\end{array}$ & $\begin{array}{c}\text { Corneal cystine crystals, } \\
\text { band keratopathy }\end{array}$ \\
\hline
\end{tabular}


Table 2 Primer sequences and polymerase chain reaction (PCR) amplification conditions

\begin{tabular}{|c|c|c|c|c|}
\hline Amplified products & Product length (bp) & & Primer sequences & PCR conditions \\
\hline \multicolumn{5}{|l|}{ Exon regions } \\
\hline \multirow[t]{2}{*}{$2-12$} & \multirow[t]{2}{*}{1,456} & Fw & $5^{\prime}$-gagacgctgagagaacctttgc- $3^{\prime}$ & a.t.: $64^{\circ} \mathrm{C}$ \\
\hline & & $\mathrm{Rv}$ & $5^{\prime}$-gagtggtctcctctgtccgc- $-3^{\prime}$ & e.t.: $90 \mathrm{~s}$ \\
\hline \multirow[t]{2}{*}{$3-7$} & \multirow[t]{2}{*}{382} & Fw & $5^{\prime}$-ccctgaagctcgtagagaaatg $-3^{\prime}$ & a.t.: $60^{\circ} \mathrm{C}$ \\
\hline & & $\mathrm{Rv}$ & $5^{\prime}$-gatggaccaggccacaaagtag- $3^{\prime}$ & e.t.: $30 \mathrm{~s}$ \\
\hline \multirow[t]{2}{*}{$7-12$} & \multirow[t]{2}{*}{842} & Fw & $5^{\prime}$-ggatctactttgtggcetggt- $3^{\prime}$ & a.t.: $60^{\circ} \mathrm{C}$ \\
\hline & & $\mathrm{Rv}$ & $5^{\prime}$-gagtggtctcctctgtccgc $-3^{\prime}$ & e.t.: $60 \mathrm{~s}$ \\
\hline \multicolumn{5}{|l|}{ Intron regions } \\
\hline \multirow[t]{2}{*}{$4-5$} & \multirow[t]{2}{*}{310} & Fw & $5^{\prime}-$ ctgattaagacaggaaggcc- $-3^{\prime}$ & a.t.: $56^{\circ} \mathrm{C}$ \\
\hline & & $\mathrm{Rv}$ & $5^{\prime}$-acctagcatttccetaccc $-3^{\prime}$ & e.t.: $30 \mathrm{~s}$ \\
\hline \multirow[t]{2}{*}{$8-9$} & \multirow[t]{2}{*}{585} & Fw & $5^{\prime}-$ gccttgcetgccetacatctc- $3^{\prime}$ & a.t.: $63^{\circ} \mathrm{C}$ \\
\hline & & $\mathrm{Rv}$ & $5^{\prime}$-acttcactcatccttggagccc- $-3^{\prime}$ & e.t.: $60 \mathrm{~s}$ \\
\hline
\end{tabular}

$F w$ forward, $R v$ reverse, a.t. annealing temperature, e.t. extension time
$160 \mathrm{bp}$. This splicing defect was further analyzed by sequencing the flanking intronic regions up to $300 \mathrm{bp}$ upstream and downstream of exon 5. The analysis showed a point mutation at position $-24 \mathrm{bp}$ (c.141-24 $\mathrm{T}>\mathrm{C}$ ) of intron 4 that was not detected in 100 control chromosomes. The predicted protein generated by exon 5 skipping was truncated at position 53 after introducing six modified amino acids at the carboxy terminal end (wild-type cystinosin: 367 amino acids).

Genomic DNA analysis failed to reveal any CTNS gene mutations in patient 3. CTNS transcripts were amplified from skin fibroblasts and demonstrated a homozygous duplication located in the exon 9 region (Fig. 1). Specifically, the messenger RNA (mRNA) sequence of exon 9 was followed by a 75-bp sequence corresponding to a portion of intron 9, located $118 \mathrm{bp}$ downstream to the exon donor splicing site and by a repeat sequence of the last $73 \mathrm{bp}$ of exon 9. At the genomic level, this transcript corresponded at position $141 \mathrm{bp}$, with a premature stop codon at position
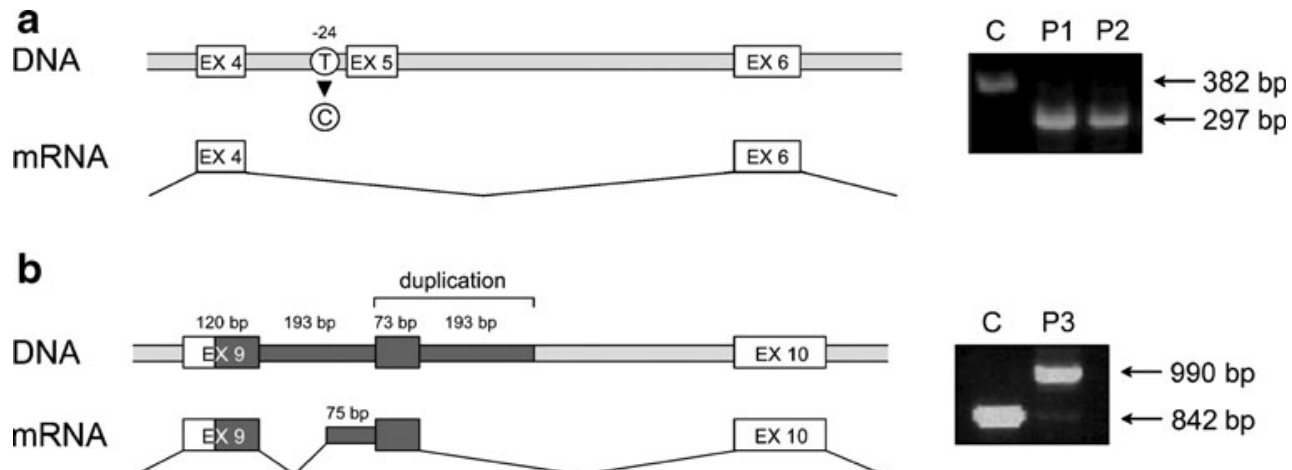

Fig. 1 Detected DNA and messenger RNA (mRNA) changes. a Patients 1 and 2 had a $\mathrm{T}>\mathrm{C}$ substitution at position -24 , upstream of exon 5 (c.141-24 $\mathrm{T}>\mathrm{C}$ ) that was not detected by standard sequencing. This mutation causes a skipping of exon 5 in the CTNS gene transcripts, as demonstrated by direct sequencing and agarose gel electrophoresis after reverse transcriptase-polymerase chain reaction (RT-PCR) amplification of the region spanning exons 3-7. The smaller band (297 bp) corresponds to the amplicon lacking exon 5 . b Patient 3 had a duplication of the genomic DNA sequence encompassing the last $73 \mathrm{bp}$ of exon 9 and the first $193 \mathrm{bp}$ of intron 9, shown in dark gray. This duplication causes an additional splicing of the mRNA transcript, with the incorporation of a portion of intron 9 followed by a repeat sequence corresponding to the duplicated portion of intron 9. By agarose gel electrophoresis using primers spanning exons 7 to 12 , a larger $990 \mathrm{bp}$ band is observed 
to a duplication of the last $73 \mathrm{bp}$ of exon 9 and the first $193 \mathrm{bp}$ of intron 9, which introduces an additional splicing site that removes the first 118 bp of intron 9. When resolved on an agarose gel, the amplicon of patient 3 produced a larger band that included 148 additional nucleotides (Fig. 1). The predicted protein was truncated at position 232 by a frameshift that generated 5 mutated amino acids, followed by a stop codon.

\section{Discussion}

In this work, two novel mutations in the CTNS gene were detected by studying CTNS mRNA transcripts in patients in whom traditional genomic sequencing failed to detect mutations in one or both alleles. Specifically, a splicing defect and a DNA duplication were identified. Analysis of gene transcripts may be limited by tissue-specific expression patterns. Fortunately, the CTNS gene is ubiquitously expressed, and accumulation of increased cystine has been demonstrated in various tissues and cell lines, including fibroblasts, proximal tubular cells, and PBMCs [15-17].

In all our patients, the clinical diagnosis of $\mathrm{NC}$ was confirmed by measuring intraleucocyte cystine levels. The splicing defect in patients 1 and 2 was located in an intronic region that is not routinely investigated $(\mathrm{T}>\mathrm{C}$ substitution $24 \mathrm{bp}$ upstream of the splicing acceptor site of intron 4). This mutation is located at a hypothetical lariat branch site and probably plays an important role in the splicing of exon 5. Lariat branch sites are crucial for appropriate splicing of pre-mRNAs, and point mutations in these regions have been shown to cause abnormal mRNA splicing [18-20]. The 266-bp DNA duplication in patient 3 could not be detected using standard sequencing primers spanning exon 9 and its immediate neighboring intronic regions. In fact, this is the first DNA duplication described in patients with NC. Apart from point mutations and small insertion/ deletions, all other mutations involve larger deletions $[3,6]$.

With this study, mutations in the CTNS gene were identified in all investigated Dutch patients, with the exception of one individual from whom RNA material was not available. Because the diagnosis of $\mathrm{NC}$ is substantiated by very specific findings, such as increased intraleucocyte cystine levels and corneal cystine crystals depositions, failure to discover mutations in these patients can be reasonably explained only by detection failures or by the existence of a second cystinotic gene. Our findings support the hypothesis that cystinosis is a monogenic disorder and suggest that CTNS transcripts should be studied when traditional genomic sequencing does not allow mutation detection. In addition, cystinosin-LKG is encoded by an alternative splicing of exon 12 and includes sequences that are located in the originally described $3^{\prime}$ untranslated region of the gene [5]. Although we have never observed mutations in this region (unpublished data), we also systematically include in our sequencing protocol the amplification of cystinosin-LKG-specific sequences.

Acknowledgments This work was supported by a grant from the Cystinosis Research Foundation (Irvine, CA, USA) and the Cystinosis Research Network.

Open Access This article is distributed under the terms of the Creative Commons Attribution Noncommercial License which permits any noncommercial use, distribution, and reproduction in any medium, provided the original author(s) and source are credited.

\section{References}

1. Gahl WA, Thoene JG, Schneider JA (2002) Cystinosis. N Engl J Med 347:111-121

2. Gahl WA, Balog JZ, Kleta R (2007) Nephropathic cystinosis in adults: natural history and effects of oral cysteamine therapy. Ann Intern Med 147:242-250

3. Town M, Jean G, Cherqui S, Attard M, Forestier L, Whitmore SA, Callen DF, Gribouval O, Broyer M, Bates GP, van't Hoff W, Antignac C (1998) A novel gene encoding an integral membrane protein is mutated in nephropathic cystinosis. Nat Genet 18:319324

4. Kalatzis V, Cherqui S, Antignac C, Gasnier B (2001) Cystinosin, the protein defective in cystinosis, is a $\mathrm{H}(+)$-driven lysosomal cystine transporter. EMBO J 20:5940-5949

5. Taranta A, Petrini S, Palma A, Mannucci L, Wilmer MJ, De Luca V, Diomedi-Camassei F, Corallini S, Bellomo F, van den Heuvel LP, Levtchenko EN, Emma F (2008) Identification and subcellular localization of a new cystinosin isoform. Am J Physiol Renal Physiol 294:F1101-1108

6. Shotelersuk V, Larson D, Anikster Y, McDowell G, Lemons R, Bernardini I, Guo J, Thoene J, Gahl WA (1998) CTNS mutations in an American-based population of cystinosis patients. Am J Hum Genet 63:1352-1362

7. Heil SG, Levtchenko E, Monnens LA, Trijbels FJ, Van der Put NM, Blom HJ (2001) The molecular basis of Dutch infantile nephropathic cystinosis. Nephron 89:50-55

8. Kleta R, Anikster Y, Lucero C, Shotelersuk V, Huizing M, Bernardini I, Park M, Thoene J, Schneider J, Gahl WA (2001) CTNS mutations in African American patients with cystinosis. Mol Genet Metab 74:332-337

9. Kalatzis V, Cohen-Solal L, Cordier B, Frishberg Y, Kemper M, Nuutinen EM, Legrand E, Cochat P, Antignac C (2002) Identification of 14 novel CTNS mutations and characterization of seven splice site mutations associated with cystinosis. Hum Mutat 20:439-446

10. Kiehntopf M, Schickel J, Gönne B, Koch HG, Superti-Furga A, Steinmann B, Deufel T, Harms E (2002) Analysis of the CTNS gene in patients of German and Swiss origin with nephropathic cystinosis. Hum Mutat 20:237

11. Mason S, Pepe G, Dall'Amico R, Tartaglia S, Casciani S, Greco M, Bencivenga P, Murer L, Rizzoni G, Tenconi R, Clementi M (2003) Mutational spectrum of the CTNS gene in Italy. Eur J Hum Genet 11:503-508

12. Fernandez-Valero EM, Ballart A, Iturriaga C, Lluch M, Macias J, Vanier MT, Pineda M, Coll MJ (2005) Identification of 25 new mutations in 40 unrelated Spanish Niemann-Pick type C 
patients: genotype-phenotype correlations. Clin Genet 68:245254

13. Alcántara-Ortigoza MA, Belmont-Martínez L, Vela-Amieva M, González-Del Angel A (2008) Analysis of the CTNS gene in nephropathic cystinosis Mexican patients: report of four novel mutations and identification of a false positive $57-\mathrm{kb}$ deletion genotype with LDM-2/exon 4 multiplex PCR assay. Genet Test 12:409-414

14. Levtchenko EN, Wilmer MJ, Janssen AJ, Koenderink JB, Visch HJ, Willems PH, de Graaf-Hess A, Blom HJ, van den Heuvel LP, Monnens LA (2006) Decreased intracellular ATP content and intact mitochondrial energy generating capacity in human cystinotic fibroblasts. Pediatr Res 59:287-292

15. Gahl WA, Bashan N, Tietze F, Bernardini I, Schulman JD (1982) Cystine transport is defective in isolated leukocyte lysosomes from patients with cystinosis. Science 217:12631265
16. Jonas AJ, Greene AA, Smith ML, Schneider JA (1982) Cystine accumulation and loss in normal, heterozygous, and cystinotic fibroblasts. Proc Natl Acad Sci USA 79:4442-4445

17. Wilmer MJ, de Graaf-Hess A, Blom HJ, Dijkman HB, Monnens LA, van den Heuvel LP, Levtchenko EN (2005) Elevated oxidized glutathione in cystinotic proximal tubular epithelial cells. Biochem Biophys Res Commun 337:610-614

18. Kuivenhoven JA, Weibusch H, Pritchard PH, Funke H, Benne R, Assmann G, Kastelein JJ (1996) An intronic mutation in a lariat branchpoint sequence is a direct cause of an inherited human disorder (fish-eye disease). J Clin Invest 98:358-364

19. Baralle D, Baralle M (2005) Splicing in action: assessing disease causing sequence changes. J Med Genet 42:737-748

20. Di Leo E, Panico F, Tarugi P, Battisti C, Federico A, Calandra S (2004) A point mutation in the lariat branch point of intron 6 of NPC1 as the cause of abnormal pre-mRNA splicing in NiemannPick type C disease. Hum Mutat 24:440 